\title{
Lapurdum
}

LAPURDUM Euskal ikerketen aldizkaria | Revue d'études basques |

Revista de estudios vascos | Basque studies review

$13 \mid 2009$

Numéro XIII

\section{Aldaerak Clovis pastoralean}

\section{Ane Loidi}

URL : http://journals.openedition.org/lapurdum/2118

DOI : $10.4000 /$ lapurdum. 2118

ISSN : 1965-0655

Éditeur

IKER

\section{Édition imprimée}

Date de publication : 1 février 2009

Pagination : 245-260

ISBN : 978-2-86781-409-X

ISSN : 1273-3830

\section{Référence électronique}

Ane Loidi, «Aldaerak Clovis pastoralean », Lapurdum [Linean], 13 | 2009, Sarean emana----an 15 avril 2013, kontsultatu 20 avril 2019. URL : http://journals.openedition.org/lapurdum/2118 ; DOI : 10.4000/ lapurdum. 2118 


\title{
Aldaerak Clovis pastoralean
}

\author{
Ane LOIDI \\ Euskaltzaindiaren Hiztegia
}

\section{Laburpena:}

Lau dira gaur egun ezagutzen ditugun Clovis pastoralaren eskuizkribu nagusiak. Horietarik bi (Bordeleko Udal Liburutegikoa eta Mauleko bilduma pribatu batean gordetzen dena) bertsio beraren aldaera dira eta beste biak (Donostian Julio Urkixo bilduman dagoena eta Baionako Euskal Erakustokiko liburutegiko bat) bertsio ezberdin banaren erakusle dira. Lehenengo aipatutako eskuizkribu biek, gainera, kopia bana dute Pariseko Liburutegi Nazionalean eta Baionako Euskal Erakustokiaren liburutegian hurrenez hurren; sei eskuizkribu, beraz, guztira. Lan honetan, gehienbat, bertsio berean oinarritzen diren eskuizkribu bien arteko aldaerak aztertuko ditugu. Itxura guztien arabera gaur ezagutzen ez dugun jatorrizko testu baten kopia eta moldaketa diren aldaera biak zertan berdintzen diren eta zertan ezberdintzen azaltzen saiatuko gara.

\section{Abstract:}

Up till now, only four main manuscripts of the pastoral Clovis are known to exist. Two of them seem to be variants of the same version; one is in the Bourdeaux Town Library, and the other one is in a private collection in Maule. The other two, on the other hand, seem to be samples of two different versions; one is in the Julio Urkixo's collection in San Sebastian, and the other one is in the Basque Museum of Bayonne. In addition to these, there are two more copies of the former ones; one of them in the National Library in Paris, and the other one in the Basque Museum of Bayonne. Therefore, there are six manuscripts in all.

Our aim in this essay is to work on the differences and similarities of the two different manuscripts of the same version. They seem to have been copied and adapted from an original text that is unknown for us nowadays.

Gako hitzak: XVIII-XIX. mendeak, herri-antzerkia, pastorala, Clovis, aldaerak, zuberera

Keywords: 18th-19th Century, popular theatre, pastoral, Clovis, variations, Basque souletine dialect

XVIII-XIX. mendeetako Zuberoako pastoraletan argitaraturik eta eskuragarri daudenak asko ez izaki, orain arte gehiegi landu ez den gaia da sujet bereko eskuizkribuen artean dauden aldaerena. A. Leonen Konstantinoplako Helena-ri buruzko lana (1909) eta J. Saroïhandyren Roland lana (1927)

1. Mila esker Iker ikerketa guneari Baionako Mintegian lan hau aurkezteko aukera emateagatik. 
aitzindari izan ziren aldaeren berri ematen. ${ }^{2}$ Batez ere lehenengoaren lanean, ezagutzen ziren eskuizkribu guztien berri ematen da eta batzuetan pasarte beraren hainbat aldaera kopiatzen dira. Charlemagne eta Sainta Catherina argitaratu dira, hurrenez hurren Oyharçabal (1991) eta Loidiren (1996) lanetan, bakoitzetik ezagutzen diren eskuizkribu bien aldaeren berri emanaz. Eskuizkribu ugari dituena da Jean de Paris pastorala ere; argitaratzeke dagoen I. Mozosen tesi lanean egin zen aldaera horien lehenengo azterketa eta oraintsu Urkizuk (2007) ere pastoral horren bi eskuizkributako aldaerak jasotzen ditu bere transkripzioan.

Eskuizkribu asko dituena izaki, aldaeren azterketarako aukera handiak ematen dituen pastorala da Clovisena ere. Erkatzen diren eskuizkribuen arabera mota bateko edo besteko azterketak egin litezke aldaerekin: hizkuntzazkoak, literaturakoak nahiz estiloari dagozkionak. Horretarako eskuizkribuen edizio egokia egitea beharrezko iruditzen zaigu eta lan horretan ari gara azkenaldian. Bertsio beraren aldaera diren bi eskuizkriburen erkaketak erakusten dituen aldaerak hona ekartzen saiatuko gara oraingoan.

\section{Eskuizkribuen aurkezpena}

Gaur egun ezagutzen ditugun trajeria zaharren artean sei dira Clovis sujeta duten XVIII. eta XIX. mendeko eskuizkribuak. ${ }^{3}$ Aurreko lan batean (Loidi 2008b) eman genuen gordetzen diren eskuizkribu guztien deskripzioa eta aipuz baino ezagutzen ez ditugunen berria. Horiek guztiek elkarren artean duten erlazioa argitzen ere saiatu ginen. Ez dugu hemen lan horretan esandako guztia errepikatuko; labur aipatuko dugu zein diren eta bakoitza non gordetzen den:

A: Guztietan zaharrena da eta Bordeleko Udal Liburutegian gordetzen da, eskuizkribuen sailean, 1695-III izendapenarekin. Guztira bi zutabetara idatzitako 51 orri dira, orrika zenbakituak, baina horietan lehenengo 16 orriak bakarrik dira Clovis pastoralari dagozkionak (567 ahapaldi, lehen eta azken peredikurik eta sataneriarik gabe) eta gainerakoek San Julian pastorala jasotzen dute. Ex libris-ean aipatzen denez, 1770eko urtarrilean Sarrikotapean egin zen emanaldian erabilitako eskuizkribua da hau. ${ }^{4}$

B: Gaur, Mauleko Peyrot anderearen etxean gordetzen da, beste dozena bat eskuizkriburekin batera, Hérelleren katalogoan $(1928,125)$ Larrieuren bildumakotzat aipatzen den eskuizkribu hau. Zenbakitu gabeko 168 orri dira, eta orrialde bakoitzak zutabe bakarrean idatzitako lau-bost ahapaldi ditu. 1405 ahapaldi zenbatu ditugu testu nagusian, 80 lehen peredikuan eta 21 ditu azken predikuak; beraz, guztira 1506 ahapaldi, marraz ezabatuta daudenak barne. Idatzitako azkenaurreko orrialdean, 1799ko data dakar, emanaldian parte hartu zuten aktoreen izenekin batera.

C: Datarik ez daraman arren badirudi XVIII. mendekoa dela eskuizkribu hau ere, hala aipatzen du behintzat Hérellek $(1928,128) .{ }^{5}$ Baionako Euskal Erakustokiko liburutegiko Campan-

2. Benetan argitaratzen lehenengo izan zen Vinsonen Saint Julien d'Antioche aipatu ez badugu ez da ahanzturaz izan, eskuizkribu bakarreko pastorala izanik aldaeren erkaketan gorabeherarik ez duelako baino.

3. Zazpigarren bat bada Baionako Udal Liburutegian. Eskuizkribu horrek XIX. mendearen hondarrean Léopold Irigaray Hérelleren kolaboratzaileak egindako Bordeleko eskuizkribuaren frantsesezko itzulpena dakar.

4. Urkizuk (2007) ortografia gaurkotuan eman du eskuizkribu honen transkripzioa. Liburu berean XVIII. mendeko beste bederatzi pastoral ere argitaratu ditu.

5. Eskuizkribuaren data antzemateko bide hoberik ez dugunez, saiatu gara paperaren ur markak irakurtzen, baina, oraingoz, ez dugu hortik argibiderik atera. 
Latsague bilduman gordetzen da 20 zenbakiarekin. 19 orri ditu guztira (letik 19ra orrika zenbakituak), eta tinta gorriz idatzita daude pertsonaien izenak eta testu oharrak. Guztira 780 ahapaldi ditu: 77 lehen peredikuak, 692 trajeriak eta 11 osorik ez dagoen azken peredikuak.

D: Donostiako Koldo Mitxelena liburutegiko Julio Urkixo bilduman gordetzen da eta 1858ko data darama (J.U. 121209799). Zenbakitutako 64 orrialdeetan eta han hemenka tartekatutako beste hainbat orritxotan jasotzen da testua: 75 ahapaldi ditu lehen peredikuak, 1419 testu nagusiak eta beste 25 azken peredikuak.

F: Parisko Biblioteka Nazionalean Celt et Basque funtsean gordetzen da ale hau 133 zenbakiarekin. Léopold Irigarayk 1899-1900 urteetan Hérellerentzat egindako kopia da, bertan aipatzen denez, V. Stempfek Bordeleko eskuizkribuari egindako kopia bat baliatuz egindakoa. ${ }^{6}$ Aldaerak aldaera, A izena eman diogun Bordeleko eskuizkribuaren kopia zehatza da.

H: Eskuizkribu hau Clement d'Andurainen bildumakoa zen, eta gaur egun Baionako Euskal Erakustokiaren Liburutegian gordetzen da 29 zenbakiarekin. Bertan irakur daitekeen data bakarra 1799koa da; hain zuzen ere, data hori daraman B eskuizkribuaren XIX. mendeko kopia baita honako hau. Akats edo gaizki ulertutako hitzen batzuk gorabehera, jatorrizkoaren berdin-berdina da kopia hau.

\section{Bertsioak eta aldaerak}

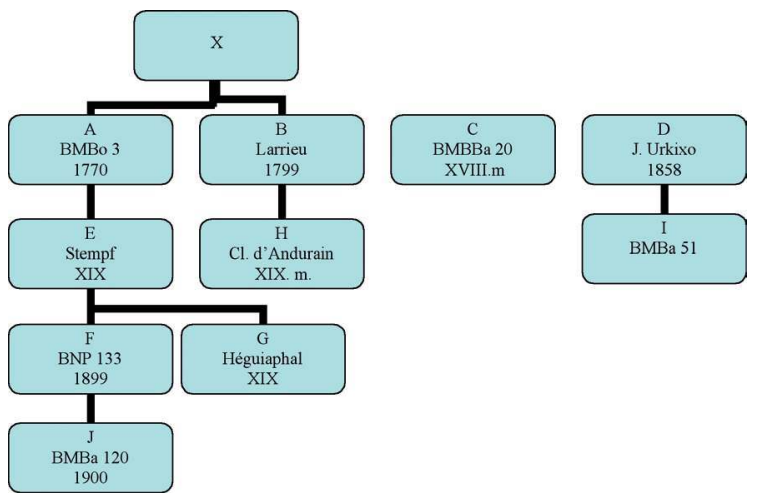

Ezagutzen ditugun eskuizkribuen gutxi gorabeherako aurkezpena eginik, eta sakonago aztertuko dugun A eta B eskuizkribuen arteko aldaeretara igaro aurretik, aipatutako eskuizkribuen artean dauden erlazioak eta horietatik sortzen diren aldaera mota ezberdinak aipatu nahiko genituzke. Horretarako, gure aurreko lanean proposatu genuen eskema bera ekarriko dugu hona: ${ }^{7}$

6. Loidi 2008b-n E (Stempf) eta G (Héguiaphal) izena eman genien eskuizkribuak ez ditugu hemen jasoko, ez baitakigu, guk behintzat, gaur egun non diren.

7. Ikusten denez, goian aipatutakoez gain, gaur ezagutzen ez ditugun Stempf eta Héguiaphalen aleak ere jasotzen ditu eskemak. Hor azaltzen da Baionako Udal Liburutegian (51 zenbakiarekin) dagoen bi orrialdeko eskuizkribua ere, D alearen pertsonaien zerrenda eta hura jokatzeko oharrak jasotzen dituena. 
Clovis pastoralaren hiru bertsio nagusi ditugu, beraz: C eta D eskuizkribuetako biak alde batetik, eta A eta Bren jatorri litzatekeen testuarena bestetik ${ }^{8}$ Bertsio ezberdinez gain A eta B eskuizkribuetatik egindako kopiak ditugu: zuzenean Btik egindako H kopia eta, kopian bertan aipatzen denez, gaur ezagutzen ez dugun $\mathrm{E}$ aletik egindako $\mathrm{F}$.

\section{Aldaeren azterketa: hiru aukera}

Jatorri eta erlazio ezberdinak ikusirik, iruditzen zaigu aldaerak aztertzerakoan gutxienez hiru erkaketa mota ezberdin egin litezkeela Clovis pastoralaren eskuizkribuen artean:

a) X, C eta D istorio beraren bertsio ezberdinak dira; aldaerak ez dira hizkuntza edo estiloari soilik dagozkionak, hori baino sakonagoak dira. Sujet berari buruzko hiru kontaketa ezberdin dira; beraz, aldaerak aztertzerakoan pasarteka erkatu beharko dira testuak, ez hitzez-hitz edo ahapaldika. Istorioak eta pasarteak zertan datozen bat eta zertan ezberdintzen diren erkatu beharko da.

b) Guztiz bestelakoa da Fk eta Hk jatorrizko A eta Brekin hurrenez hurren duten erlazioa. Bi kopia horiek, eta batez ere bigarrena, jatorrizkoaren oso berdinak dira. L. Irigarayk egindako kopia (F) Hérellerentzat zen, beraz, Zuberoako teatroaren ikertzaile handiari Bordeleko testua eskuragarriago egitea zuen helburu, eta ez emanaldi berri baterako testua moldatzea eta idaztea. ${ }^{9}$ Kopia horrek, beraz, definizioz izan behar du leiala eta jatorrizkoaren berdina. Hri dagokionez, berriz, ez dakigu benetan zer helburu zuen, baina horrek ere emanaldi berri baterako egina baino bestelako helburuekin egina dirudi. Ez dakigu nork kopiatu zuen, baina iruditzen zaigu izan litekeela Cl. D'Andurainek berak norbaiti kopiatzeko eskatua (ezagutuko zituen, ziur aski, Larrieuren bildumako eskuizkribuak) edota, zergatik ez, Fr. Michelek, urte batzuk lehenago, B eskuizkribua esku artean izan zuenean egin edo eginarazitako kopia. ${ }^{10}$ Batak, besteak, zein hirugarren batek egina izan, helburua jatorrizkoaren kopia zehatza egitea zen eta, hala, jatorrizkoan marraz ezabaturik dauden ahapaldiak ere kopiatu eta berdin-berdin marraz ezabatu dira. Bi kopia horietan, beraz, aldaeren azterketa jatorrizkoarekiko hitzez-hitzeko eta ahapaldiz-ahapaldiko erkaketan oinarritzen da. Nahita egindako aldaketa eta moldaketak barik, oharkabean-edo egindako aldaerak aurkituko ditugu. Gure oraingo lan honen funtsa hirugarren sailean aipatuko ditugun aldaeren azterketa da, eta beraz, ez ditugu F eta H kopietako aldaerak gehiegi aztertu. Dena den, badirudi Hko aldaera gehienak hutsak edota irakurketa okerrek sortuak direla. L. Irigarayren kopian, berriz, horiez

8. Loidi 2008b-n ere aipatu genuen ez dela ezinezkoa B eskuizkribuaren jatorrizkoa A izatea eta ezberdin duten guztia bigarren honek moldatua eta gehitua izatea, baina, besteak beste, Bren bigarren zati guztia ulertzeko egokiago iruditzen zaigu hemen ere X izendatu dugun jatorrizko testu horri eustea. Beraz, erkaketak egiterakoan eta aldaerak aipatzerakoan lan honetan eskuizkribu biak zuzenean beste hirugarren batetik kopiatuak balira bezala jokatuko dugu.

9. Goian ikusi dugunez testu horren itzulpena ere egin zuen Irigarayk Hérellerentzat.

10. Loidi 2008b lanean azaldu genuen Fr. Michelen eta B eskuizkribuaren arteko erlazioa. Gure ustez eskuizkribu hori erabili zuen frantziar ikertzaileak Le Pays Basque liburuan (66-75) eman zuen Clovisen laburpena eta transkripzioa egiteko eta A. Oihenarten poemei egindako edizioaren hitzaurrean (LXIX. orrialdeko oinoharra), bere eskuizkribuan azaltzen diren pertsonaia eta aktoreen zerrenda kopiatu zuenean.

11. Hutsei eta irakurketa okerrei dagokienez kopia honetan kontuan izan behar da, gainera, ez dela zuzenean Atik egina, Stempfen kopia baliatuaz egina baizik; beraz, hutsak bikoiztuak izan litezke eta horien azterketa zaildu egiten da, ez baitugu askotan ziur jakiterik izango irakurketa okerra Stempfengandik jasoa den ala Irigarayk berak egina. 
gain, ${ }^{11}$ bada hizkuntzazko aldaerarik ere. ${ }^{12}$

c) Hirugarren modu batean aztertu behar dira A eta B eskuizkribuen artean dauden aldaerak. Eskuizkribu bi horiek beste hirugarren testu batetik egindako kopiak dira, baina ez dira goian aipatu ditugun F eta H kopiak bezala egindakoak. Bi horiek Clovis pastoralaren emanaldi banatarako prestatutako testuak dira; batean zein bestean kopiaren egilea ez da kopiatzaile huts, testuaren moldatzaile eta berridazle ere bada aldi berean. Kopia diren aldetik, beraz, badituzte hutsak eta irakurketa okerrek sortutako aldaerak ere, baina kopiatzaile eta moldatzaileak nahita egindako aldaerak dira nagusi. Jatorrizko testua ezagutzen ez dugunez ezin jakin dezakegu kasu jakin bakoitzean zein den jatorrizkotik bereizten dena eta zein jatorrizkoari leial eutsi diona.

Hiru erkaketa molde horietan, A eta B eskuizkribuen artean dauden aldaeren azterketa aukeratu dugu lan honetarako.

\section{A eta B eskuizkribuen arteko aldaerak}

Goian egin ditugun deskripzio laburrak aski dira bi eskuizkribu hauek berdin-berdinak ez direla ohartzeko: zaharrenak 567 ahapaldi bakarrik ditu eta berrienak, berriz, 1506; lehenengoak lehen eta azken peredikuak falta ditu eta sataneriarik ere ez du eta bigarrenak, berriz, bai. Ezberdinak izanik ere, ordea, badituzte hainbat ahapaldi berdin-berdinak. A eskuizkribuaren kontaketa B eskuizkribuaren lehenengo zatiarekin bukatzen da, gutxi gorabehera bigarren horren 570 . ahapaldian; hortik aurrera Bn kontatzen dena, beraz, ez du jasotzen Ak (beste 830 ahapaldi inguru). Clovisen bataioarekin eta liz lorearen inguruko pasartearekin bukatzen da Bordeleko eskuizkribuaren kontaketa. Pasarte horretara bitartean, 400 ahapaldi inguru dira bietan berdinak, eta bakoitzak beste 160-170 ahapaldi ezberdin ditu gainera. Biek berdin dituzten ahapaldi horietan aurkitu ditugun aldaerak erakutsi nahi ditugu batez ere lan honetan, ez guztiak banan-banan baina bai orokorrean eta multzoka antolaturik. ${ }^{13}$

Ahapaldi "berdinak" aipatzen ditugunean jatorriz berdinak diren ahapaldiak aipatu nahi ditugu, alegia, aldaerak gorabehera testu bera dutenak. Ikus ditzagun hainbat adibide:

Batzuetan berdin-berdinak dira, A 63 eta B 102 diren bezala:

A 63 Bena ez bestela, eniroçu eguin seculla, ceren nahy beiniz isseiatu arimaren salvatcera.
B 102 Bena ez bestela, eniroçu eguin secula, ceren nahy beiniz isseyatu arimaren salvatcera.

12. Aztergai bikaina iruditzen zaigu A eta F eskuizkribuen artean dauden aldaeren azterketa, baina, oraingoan beste sail bati helduko diogunez, goian aipatu dugunaren erakusgarri diren adibide batzuk bakarrik ekarriko ditugu hona: jatorrizkoan asimilazioarekin azaltzen diren triatin, emaitin eta jun, triatian, emaitian eta juan dira Fn; palatalizaziorik gabeko esparantza, bakhoitz, egotzi eta hanitz edo gaizkia, adiskidia eta gaiztua palatalizaziodun esparantxa, bakhoitx, egoitxi eta hanitx edo gaixkia, adixkidia eta gaixtua dira; ablatiboko - $t i$ eta soziatiboko -ki -tik eta -kin dira kopia berrienean; era berean zaharrenean baizi dena baizik da Irigarayren kopian; nure, nureki eta ore ene, eneki eta hire bihurtzen dira; aditz formetan ere badira aldaerak, luzeegi joko lukeenez, hona ekarriko ez ditugun arren.

13. Ahapaldietako testuan dauden aldaerez gain didaskalia edo testu oharretan ere badira ezberdintasunak eskuizkribu bien artean. Beste baterako utziko dugu horien azterketa, baina, oro har, esan liteke osoagoak eta zehatzagoak direla B eskuizkribukoak. Pertsonaien izenen erkaketa ere ez dugu hemen egingo. Pertsonaia nagusien izenak berdinak dira eskuizkribu bietan, baina bigarren mailako hainbat izen ezberdin azaltzen dira. 
Beste batzuetan hitzen bat edo bitan bereizten dira, edo hitz gehiagotan bereizi arren egituraz berdinak dira:

A 365 Sira, ez haboro pacentcia, ditçagun ataca mementian; asse nahy nundukeçu coky haien odollian.

A 352 Ouste baduçu deus ary dela, othoy eçaçu ny gatiq Ginco houra, eztit deliveratcen orano nouriaren uztera.
B 403 Sira, ez haboro pacencia, ditçagun atçaman mementian; asse nahy nunduqueçu coqui hayen odolian.

B 389 Ouste baduçu hobe dela, othoy ecaçu çoure Ginco maitia, eztit deliberatcen orano nouriaren uztia.

Jarraian kopiatu ditugun A 353 eta B 390 ere berdintzat hartzen ditugu, ahapaldiaren bigarren zatia ezberdina izanik ere, aurretik eta ondoren datorrena berdina dutelako. Berdin duten zatia jatorrizko ahapaldi beretik kopiatua behar dute biek.

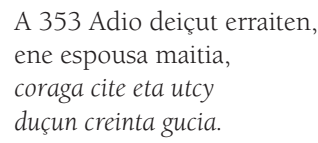

\author{
B 390 Adio deiçut erraiten, \\ ene espousa maitia, \\ luce içanen citaçu \\ berriz çoure bessarcatcia.
}

\subsection{Pasarte edo zati handi bat hartzen duten aldaerak}

Berdin dituzten ahapaldien aldaerak aztertu aurretik ezberdin dutena gutxi gorabehera azaltzen saiatuko gara: badirudi eskuizkribuak hasieran eta bukaeran bereizten direla gehien, beste guztia berdintsuago doala. Esaterako, bietan berdina den lehenengo ahapaldia Ako 11.a eta Bko 39.a dira; ahapaldi hori iritsi arte Clovisen eta Aurelianen arteko elkarrizketa ezberdin doa. Hasiera hori gainditurik, Aurelianek Clotildarekin hitz egitea lortzen duen arteko guztian badira gorabeherak; bina-hiruna ahapaldi berdinak aurkitzen baditugu ere, tarteka ezberdinak diren beste sei-zortzi ahapaldiko multzoak ditugu. Clovisek Aurelian Borgoinara bidali duenean Aurelianek hara nola iritsi aztertuaz izan duen bakarrizketa dator eskuizkribu bietan (A 18-29 eta B 47-57 ahapaldietan). Bakarrizketa horretan, Clovisen mezulariak, Gundebant ohartu gabe Clotildarekin hitz egiteko zer egin behar duen aztertzen du. Aurelianek badaki bere gizon guztiekin joaten bada Gundebant ohartuko dela eta, txarrera harturik, Clotilda bera hil ere egin dezakeela, haren aita eta familiarekin aurrez egin zuen bezala. Beraz, jakinik Clotilda egunero meza entzutera joaten dela eta ondoren behartsuei laguntza ematen diela, pobre jantzian eta bakarrik joatea erabakitzen du. Kontaketa horretan, baina, ahapaldi guztiak ez dira berdinak. A 18 / B 48 eta A 27 / B 57 dira ahapaldi berdin bakarrak eta A 21-22 / B 53rekin eta A 26 / B 55-56rekin oso antzekoak dira. Beraz, pasarte honek bi ahapaldi bakarrik ditu berdin-berdinak eta beste hiru antzekoak. Oso zail da jakiten zati honetan zein izan den jatorrizkotik bereizi den moldatzailea eta zein hari leialago izan zaiona. Ez dira ahapaldi bat edo bi gehitu edo kendu direnak, tarteko zortzi ahapaldietan zehar ezberdin doa kontaketa.

Goian aipatu dugun pasartearen ondoren Polis behartsuarena eta Aurelianek eta behartsuak elkarrekin duten elkarrizketarena ere ezberdinak dira. An ez bezala, Bn behartsuaren bakarrizketa dator lehenengo (B 59-65), dela ikusleei, dela oholtza gainean leudekeen pertsonaia ikusezin batzuei amoina eskatuaz... Pasarte horretan hasi eta Aurelianek Clotildarekin duen lehenengo elkarrizketarainoko bideak elkarren inguruan baina bereiz doaz eskuizkribu bietan, harik eta A 53 
/ B 91 ahapaldietan berriz bat egiten duten arte. Hortik aurrera bateratsu doaz ehun ahapalditik gorako pasarte luze batean, tarteka Ak ahapaldiren bat gehiago duela.

Horietan guztietan oso zail da jakiten zein den bietan berritzailea. Dena den, Clovis kristauaren eta Jule turkaren arteko borrokaldiaren emaitza da kontaketaren harian gorabehera handiena dakarren zati ezberdina, aurreko lanean ere aipatu genuenez. Eskuizkribu bietan berdin datozen ahapaldietan, Clovisek Juleri konbertitzeko aukera ematen dio, baina A 443 eta B 458tik aurrerakoa ezberdina da:

JULE

A 444 Clovis, çuq placer duçuna ezpere eguinen dit, bena behar naiçu, othoy, utcy biciriq

445 eta çoure exempliary bertan nuçu jarraikiren, noure gincouaq kitaturiq khiristy errendaturen

446 eta çuq manhatiaq oro gogo hounez citit eguinen, eta reparationetaco noure coroua, aldiz, emanen.
JULE

B 458 Ale, debru esquelia, enuq ossoquy loxatu oray hiry nahy dat buria ondoty trencatu.

Batailla; Jule hil.

Pasarte horretan hartu duten bide ezberdinak ahapaldi batzuk beherago ere bide bereziak hartzera daramatza kopiatzaileak:

\section{CLOVIS}

A 482 Nestorin, Franciarat behar diagu phartitu, habororiq egon gabe mementouan abiatu.

483 Adio erraiten deriçugu, Jula, mementian, eta egon cite bethy, othoy, çoure hitcian.

JULE

484 Adio, Clovis, adio,

Franciaco erreguia;

bidage houn souhetatcen deiçut eta bicitce lucia.

485 Desobedienciariq ene aldetiq secula eztuçu ginen eta baliman çoureky gerlariq eztit ukenen.

\section{CLOVIS}

B 501 Nestorin, Franciarat behar diçugu phartitu, haboro egon gabe mementouan abiatu.

Abia eta recontru eguin.

Badirudi, kasu honetan Bko kopiatzailea aldentzen dela jatorrizkotik, baina garbi dago ohartuki hartutako bidea izan dena; 501. ahapaldian, goian hartutako bideari eutsiaz, B eskuizkribuan Clo- 
visek ez du Jule agurtzen Frantziara abiatzerakoan.

Besteak beste horrelako pasarteak ikusirik, garbi esan liteke eskuizkribu horiek kopiatu dituztenak ez direla kopiatzaile huts; hainbatetan moldatzaile eta sortzaile dira, eta egindako aldaketa eta moldaketak aurrez antolatutako kontaketa batean gauzatzen dira. Bitxia da alde horretatik ondoren aipatuko dugun pasartea. B 231-232 ahapaldiek erakusten dute jatorrizko testuak A-k dakarrena edo antzeko zerbait zekarrela bi ahapaldi horien tartean, eta Bko kopiatzaileak zati hori ez kopiatzea erabaki duela. Zati hori kopiatu gabe utzi duenean, ordea, testuak jarraikortasuna falta du eta hutsune hori salatzen du. Bko ahapaldiak bakarrik irakurrita ez da ulertzen zer diren Clotildak gogo onez utziko lituzkeen beste gauzak. A eskuizkribuak tartean dakarrena irakurrita ulertzen da zer falta den eta Bk zer ezabatu duen:

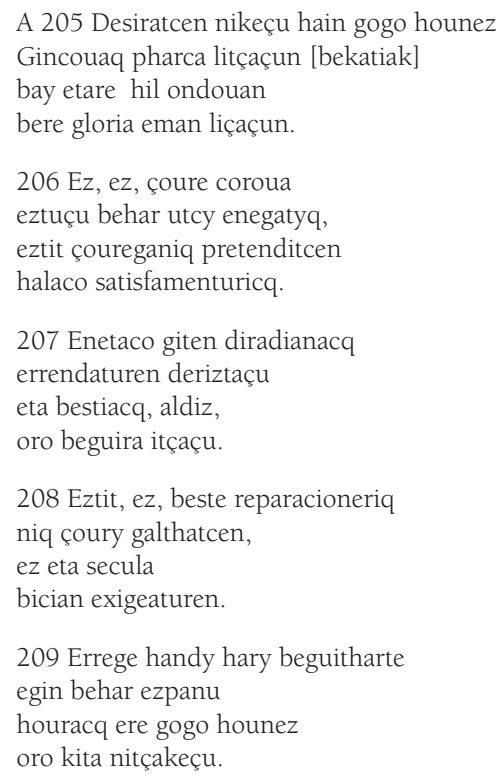

B 231 Desiratcen niqueçu Gincouaq pharca litçaçun [bekatiak] bay eta hil ondouan bere gloria eman liçaçun.

Dirudienez, baina, ez gara gu izan hutsegite horrekin ohartu garen bakarrak; Bko kopiatzailea ere ohartu bide zen, 232. ahapaldia goitik beherako bi marraz ezabaturik baitago eskuizkribuan.

\subsection{Ahapaldi barruko aldaerak}

Goian aipatu ditugun aldaera guztiak nahita egindakoak izan dira, alegia, kopiatzaileak, bere testua antolatzerakoan, jatorrizkotik bereizi nahi izan du batzuetan eta halaxe egin du. Oraingo sail honetako aldaera guztiak ez dira mota horretakoak. Asko dira hemen ere kopiatzaileak egokiago iritzita egindako aldaketak, baina badira kopiatzerakoan egindako hutsak salatzen dituzten aldaerak ere.

\subsubsection{Ohartuki egindako aldaerak}

Eskuizkribu bi hauen artean dauden aldaeretan kopiatzaileak nahita egindakoak dira gehienak; denak aipatzen hasita sail hau luzeegi litzateke lan honen neurrirako, eta hortaz, adierazgarrienak bakarrik aipatuko ditugu: 


\subsubsection{Hitzak}

Sail honetan aipatuko ditugun gehienak sinonimoak edo sinonimo antzekoak dira. Askotan euskal jatorriko hitza (zentzurik zabalenean) eta maileguzkoa daude aurrez aurre. Behean, lehenengo bi multzoetan banaturik ezarri ditugun adibideetan ikusten denez, ez da beti eskuizkribu bat bestea baino garbizaleagoa; kasu batzuetan A eskuizkribua da mailegua darabilena eta B euskal hitza aukeratzen duena, baina beste alderako adibideak ere berdin-berdin aurkitzen ditugu. Lehengo bi multzo horien ondoren emango ditugu gainerako sinonimoak, hizkuntza aldetik bereizketa hori ez dutenak: ${ }^{14}$

A 88 aiutaturen / B 125 lagunturen, A 143 espousataco / B 174 emaztetaco, A 151 susprenitu / B 182 edireiten, A 175 exigeatcen / B 206 eguruquiten, A 386 ayutia / B 418 laguntça, A 382 conkeritu / B 415 çaticatu.

A 75 gaitcetaricq / B 113 malheurriq, A 82 Virgina Maria eztia / B 119 sacratia, A 88 lagunturen / B 125 favorituren, A 187 atçamaitiagaty / B 218 usurpatciagaty, A 129 eguiaz / B 162 sinceroquy, A 332 elhestatu / B 370 consultatu, A 324 jauz erazi / B 364 trenkatu.

A 156 chahaturen / B 187 galeraciren, A 410 arhincen / B437 alchatcen, A 64 regretiq / B 103 anxiariq, A 419 ajutaturen / B 443 sokhorrituren, A 420 socorritu / B 444 favoritu, A 470 secoursaren / B 492 sokhorriaren, A 80 delibra / B 117 libra, A 53 dama / B 91 princessa

\subsubsection{Esaldi osoak}

Sail honetan datozen adibide gehienak ezberdin moldatutako esaldiak dira, ahapaldiaren itxura gehiegi aldatu gabe egindako bariazioak eta hainbatetan egitura morfosintaktikoari dagozkionak:

A 12 Har eçaçu diharu, gente eta arma, bay eta jouan bertan printcessa haren edireitera.

\section{A 155 Çouin nahy guisatara} ossoky galdia niz, ecin ukeiten ahal dut batere ressoursaricq.

A 364 Hicq beçala ihourq ere ezkiticq secula naussatu; ale fripoua, aleta, sarry behar ducq phacatu.
B 40 Har eçaçu diharu, gente eta arma, eta lehen beno lehen jouan princessa harengana.

B 186 Çoin nahy guisetara ossoquy niz galduriq, ecin ukhaiten ahal dut batere resourçariq.

B 402 Hiq beçala ihourq ere ezquitiq secula naussatu, bena debria ezpaduq sarry behar duq phacatu.

14. Nahita egindako aldaketen sailean sartu baditugu ere, aldaera horiek ez dira beti eta ezinbestean halakoak. Gerta liteke hainbatetan kopiatzaileak gogoan hartu duen esaldia idazterakoan hitz baten ordez haren sinonimo edo pareko bat kopiatzea oharkabean. Horrelakoetan zail da jakiten benetan aldaketa hori kopiatzaileak nahita ala oharkabean egin duen. 


\author{
A 121 Sira, irous lukeçu Francia \\ houra erreguina balin baliz; \\ ez umen diçu mundian \\ hareq bere parericq.
}

B 154 Sira, irous luqueçu Francia houra balin baliz erreguigna; entçun diçut mundian haren pareriq eztela.

Hurrengo lerroetan parez pare datozen ahapaldietan alde bateko bakarrak besteko bien laburpen modukoa-edo dirudi:

A 21 Clotilda galeracy liro, aldiz, jakin baleça mementian eta gu oro ere benturaz dembora berian.

\section{Haren aita eta ascaciacq} corouaren atçamaiteco oro galeracy uken çutian guero
B 53 Jaquin baleça, aldiz, Clotilda galeracy liroque, haren ascaciaq beçala bertan hil eracy liroque.

B 55 Ençutia dit princessa houra ecinago devota dela eta meçaren ençutera egoun oroz jouaiten dela. egun oroz meça entçutera jouaiten dela eta prauber amouinaren emaitera,

56 Meça ençun ondouan diala prauver amouina emaiten, eta eliça murru ondouan prauveq eguruquiten.

\subsubsection{Oharkabean egindako aldaerak: hutsak nahiz bestelakoak}

Sail honen izenburuan jarri dugunez, oharkabean egindako aldaketa guztiak ez dira kopiatzailearen hutsak ezinbestean. Aldaera fonetikoak, esaterako, oharkabean egin ditzake kopiatzaileak, jatorrizkoan forma bat irakurririk ere bere hizkerakoa idazteko joera izan dezakeelako. Ezin esan, hala ere ezinbestean oharkabean eginak direnik, kopiatzaileak ohartuki ezar baitezake aldaera baten ondoan bereago duena edo zuzenago irizten diona.

\subsubsection{Forma-aldaketak}

Askotariko aldaerak (hala morfologiarekin zerikusia dutenak nola aldaera fonetiko hutsak, adibidez) bildu ditugu izen zabal honen azpian, lan honetan aldaeren tipologia edo azterketa zehaztea baino gehiago interesatzen zaigulako aldaerak ikusaraztea. Gainera, ez da beti erraza, pastoralen eskuizkribuetan, hainbat aldaera grafikoren atzean zer den asmatzea. Esate baterako, badirudi, A eskuizkribuak ez duela beti berdin markatzen $k$ hasperenduna, beraz, A 43ko murru baten cantian eta B 78ko murru baten khantian motako aldaerak ez ditugu hemen aipatuko, An bertan baitatoz Hire khantiala $(177)$ eta Orleanxe khantiala $(466,473)$ adibideak ere. ${ }^{15}$ Horrekin esan nahi duguna da, es-

15. Loidi 2003-2004ko hitzaurrean, grafiari buruzko atalean, aztertu genuen eskuizkribu berean datorren San Julian pastoraleko herskari ahoskabe belarra adierazteko grafia ezberdinen erabilera. Gainerakoan ere B eskuizkribuko grafia Akoa baino sistematikoagoa eta arautuagoa dela esan daiteke. An badira espero genukeen grafiaz bestelakoa duten adibideak: errege $(124,145,157 \ldots)$, gerla $(139,144,156 \ldots)$, aphurregy (157) aurki dezakegu erregue, guerla edo aphurreguy-ren lekuan, vengaturen (164) venjaturen-en lekuan, bacuian (423) baquian-en ordez edo escele (328) eskele edo esquele-ren ordez (baditu eskele (49) edo ezquelia (433) ere). 
kuizkribuetan iritsi zaigun adierazpen grafiko ezberdinak ez duela beti aldaera fonetikoa adierazten eta, beraz, benetako aldaera fonetiko baten isla iruditu zaizkigunak bakarrik jaso ditugula hemen. Hona, beraz, sail honetan aurkitu ditugun aldaera nagusiak:

A u / B o: A 65 çouintan / B 104 çointan, A 155 çouin / B 186 çoin, A 231 ounxa / B 261 onxa, A 248 hounky / B 286 honky, A 252 hountarçun / B 289 hontarçun, A 276 gouraintcy / B 319 goraincy, A 289 souein / B 326 soin, A 342 coueintariq / B 380 cointariq, A 342 çounbaitecq / B 380 çombaiteq;A 477 noublia / B 498 noblia.

A o / B u: A 137 boket / B 169 bouquet, A 177 nola / B 208 noula, A 346 corajousky / B 384 courayousquy.

A ü / B u: A 42 egun / B 77 egoun. ${ }^{16}$

A e- / B i-: A 104 ekoussy 17 / B 140 ikhoussy, A 143 egorten / B 174 igorten.

A -ld- / B -lth-: A 138 galdatcera / B 170 galthatcera, A 163 galdatcia / B 194 galthatcia, A 202 galda egiten / B 228 galthatcen, A 311 galdoua / B 352 galthoua, A 500 galda eçaçu / B 509 galtha çaçu (ik. A 170 / B 201 eta A 386 / B 418 ere). ${ }^{18}$

A 185 egotcy / B 215 egoitxy, A 253 hanitcez / B 290 hanitchez. ${ }^{19}$

A 61 eta 247 hau / B 100 eta 285 haur.

A 65 çoureky / B 104 çourequin; A 41 baicy / B 76 baiciq; A 84 haregatiq / B 121 haregaty, A 405 hilciagatic / B 433 hilciagaty.

A 169 deriçugu / B 200 deiçugu, A 269 eta 279 deriçut / B 306 eta 322 deiçut, A 403 dereiat eta betereiat / B 431 derat eta beiteriat, A 409 dereiciet / B 436 deritciet.

A 129, 342 duia / B 162, 380 dia, A 336 nunduia / B 411 nundia.

A 299 eskilinba / B 342 esplinga, A 340 deligenta / B 378 deligentcia, A 345 destroua / B 383 destrona, A 363 aleta / B 401 areta, A 385 aflegitu / B 417 afligitu, A 402 geiqui / B 430 jaiqui, A 406 porocatu / B 434 phorroscatu, A 413 paillat / B 438 paillaz, A 467, 468, 494 archebesco / B 489, 490, 507 archevisco, A 533 firiq / B 556 finiq, A 349 protector / B 386 protetore, A 372 balentia / B 408 balentria.

A 115 premety / B 149 permety, A 305 premetitcen / B 348 permetitcen, A 149 premissione / B 180 permissionia, A 221 premissioniareky / B 244 permissionarequy, A 235 premissionia / B 264 permissionia; A 135 ususpaturiq

16. Ez da hori B eskuizkribuko adibide bakarra; egoun da agerraldi guztietan azaltzen den aldaera.

17. Ahapaldi zenbaki bakarra jarri dugu eskuizkribu bakoitzarentzat, baina ek(h)usi da A eskuizkribuan forma nagusia (ikusi bi aldiz aurkitu dugu: icousiren 413 eta icousi 436) eta Bn, berriz, beti ikhusi aurkitu dugu. Bitxia da Clovisen A eskuizkribuan eta San Julianen ia bakarra den ekusi aldaerak ez duela Orotariko Euskal Hiztegian zubererako adibide bakar bat ere.

18. Ak batzuetan badakar galthatu ere (53, 100, 197, 208, 214, 259, 266, 279, 332, 387, 479, 509).

19. Bk ere gehienetan hanitz dakar. Ik. 350, 377, 491, 570. 
/ B 167 ussurpatu, A 179 ususpatu / B 210 ussurpatu; A 139 arcordatu / B 171 accordatu (ik. 143 / 174; 156 /187; 170 /201 ere); A 202 satifamentu / B 228 satisfamentu.

Goian aipatu dugun aldaera grafikoen mugan daude, gure iritziz, err- / re- edo s- / es- motako aldaerak. Ia ziur esan liteke spiritu eta rezebitu grafia etimologikoak eragindako aldaerak direla, baina hemen aipatuko ditugu. Kasu honetan ere ez da beti eskuizkribu bat grafia "euskaldunagoaren" hautua egiten duena:

A 71 remestiatcen / B 110 erremestiatcen, A 143 repostu / B 184 arrapostu, A 221 repostia / B 244 arrapostia, A 165 retiratu / B 196 erretiratu, A 98 spiritu / B 135 ezpiritu.

A 89 errecevitu / B 126 recebitu, A 304 erremedioricq / B 347 remedioriq, A 162 arrafusatcen / B 193 refusatcen.

\subsubsection{Irakurketa edo kopiatze hutsak}

Eskuizkribuetan kopiatzerakoan egindako hutsak harrapatzea eta huts horien jatorrian zer zegoen asmatzea ez da erraza gehienetan. Onenean ere esaldi bitxi edo nahasiren bat edo gauza ulergaitzen bat badela suma dezakegu hainbatetan. Eskuartean ditugun eskuizkribuen moduko kasuetan, errazagoa da hutsak harrapatzea, huts egin duenaren ondoan zuzen irakurri duen kopiatzailearen aldaera baitugu. Horrelako zerbait gertatzen da hona ekarriko dugun lehenengo adibidearekin. A 182ren parean B 212 izango ez bagenu, agian ez ginatekeen jabetuko kopiatzailearen hutsarekin; bitxia irudituko zitzaigun, bai, Jesukristoren ondoan gurutziltzatutako ohoinak ez baitzuen anaia hil, baina zail egingo zitzaigun, seguruenera, zuinek horren lekuan Kainek irakurri behar dela konturatzea. Hain zuzen ere horixe argitzen digu B 212 ahapaldiak.

\author{
A 180 Minçatcen ahal niça ouhouina \\ Jesus Cristy beçala? \\ Ez, ez, hala ere \\ eniten ahal bentura;
}

181 etcinna niq beçain crima handiriq ouhouin hareq cometitu, niq beçain criminelky bere odolian bere eskiaq trempatu.

182 Çouineq bere anaia bera baicy etcina besteriq erho, ene crima dun, ene crima, harena beno ere handiago.

\author{
B 211 Minçatcen ahal niça ohoin houna \\ Jesu Christy beçala? \\ Ez, ez hala ere \\ eniten ahal bentura.
}

Hurrengo aipatuko dugun adibidea ere antzekoa da, baina oraingoan badirudi hutsa egin duena Bko kopiatzailea izan dela:

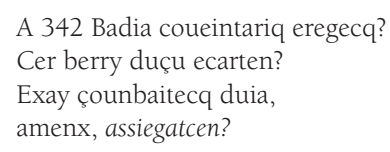
212 Kaineq bere annaya baicy etcina besteriq erho, ene crima dun harena beno milatacouaz handiago.

Jarraian datozen bi adibideetan ez da erraza esaten zer zen jatorrizkoak zekarrena eta zein den testua aldatu duen kopiatzailea; oharkabean eginak ala ohartuki eginak diren esatera ere ez gara ausartzen, baina badirudi lehenengoan Bk egin duela lardatu > tratatu aldaketa eta bigarrenean, 
berriz, A izan dela hartzen > harritzen egin duena:
A 373 Cokiacq, behar ducie
B 409 Coquiaq, behar ducie
orocq maradicatu,
oroq maradicatu,
aphouaq gerrenetan beçala
aphouaq guerrenetan beçala
nahy çutiet lardatu.
nahy çutiet tratatu.
A 328 Aguer ady, fripou escelia,
B 367 Aguer ady, fripou esquelia,
devriacq ezpahay harritcen,
debriaq ezpahay hartcen
bay eta goure loxaz
ossoky incantatcen!
eta goure loxaz oray
ossoquy incantatcen!

A 335 eta B 373 ahapaldietan, berriz, badirudi egindako esaldi bat dugula, eta Bko kopiatzaileak, esaera ezagutzen ez duenez, gaizki kopiatu duela:
A 335 Jokha nirocq bicia
B 373 Jokha niroq bicia
houra beita erhouaren gagia,
houra beita horen gagia,
eracarry nahy ahal diala
erakarry nahy ahal diala
Franciaco erreguia.
Franciaco erreguia.

Euskaraz antzekorik aurkitu ez badugu ere, 1787-1788ko Jean-François Féraud-en Dictionaire critique de la langue française hiztegian "c'est la gageure d'un fou" esaera aurkitu dugu: "eroaren apustua", beraz. ${ }^{20}$

A 475 eta B 496 erkatuaz ikusten da Ako kopiatzaileak egin duela hutsa, baina, aurrekoak jatorrizko testua irakurtzerakoan egindako hutsak badira, oraingoan badirudi irakurtzerakoan barik idazterakoan erratu dela:

A 475 Behar gutuçu laguntu, monseigneur, çuq, othoy, hiry hartara;

behar duçu hara gin

erregeren batheiatcera.
B 496 Behar gutuçu laguntu, monseigneur,

çuq, othoy, hiry hartara;

behar diçugu hara jouan

Clovisen batheyatcera.

A 133 eta B 165ekoak ere, izatekotan, irakurtzerakoan egindakoa baino gehiago idazterakoan egindako hutsa dirudi; oraingoan badirudi B erratu dela:

A 133 Cer den ounxa eta gaizkia segurky harecq baçakiçu; haren spiritiaren parericq mundu hountan eztuçu.
B 165 Cer den onxa eta gaisquia segurquy hareq baçaquiçu; haren ezpiritiaren pareriq mundu orotan eztuçu.

20. Honela dio hiztegi horrek "gage" sarrerako "gager" azpisarreran: "Parier [...]. Gager avec ou contre quelqu'un. = On dit proverbialement, je gage ma vie, ou ma tête à couper, et quelquefois on répond: c'est la gageure d'un fou." 
Hurrengo adibidekoak ere idazterakoan egindako hutsa dela dirudi, baina oso zail da jakiten bietan zein erratu den, edo ohartuki testua zeinek aldatu duen. Oraingo honetan errima daramaten hitzak lekuz trukatu ditu kopiatzaile bietatik batek:

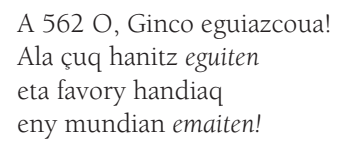

\author{
B 570 Oh, Ginco eguiazcoua! \\ Ala çuq hanitz emaiten \\ eta favory handiaq \\ eny mundian eguiten!
}

A 145 eta B 176 ahapaldiak aurrez aurre jarrita, ohartzen gara badela Ako ahapaldian laburtu beharrez-edo egindako zerbait Bn argiago datorrena:

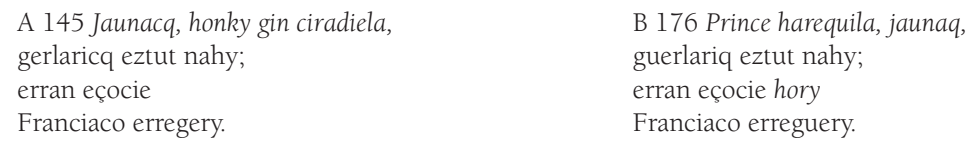

Aldaera kontrajarriak dauden guztietan, baina, ez dugu irakurketa okerrik ikusi behar, hainbatetan kopiatzaileak nahita egindakoa izan baitaiteke. A 331n Erregue edireiten da / amini bat indisposaturicq dioen lekuan, esaterako, ossoky indisposaturiq dakar B 369k, baina ez dago bataren edo bestearen hutsa dela zertan pentsatu, bietako edozeinek ohartuki egindako aldaketa izan bailiteke. Gauza beretsua esan liteke A 401eko orory / jauceraciten deitciet erchiac eta B 429ko orory deritciet / jauz eraciten buriaq esaldiari buruz.

A 378n Jupiter dioen lekuan B 414n Barlaman irakurtzen dugunean ere ez da erraz jakiten nahita egindako aldaketa den ala oharkabean egindakoa; hala ere badirudi B izan dela aldatu duena. A eskuizkribuak Jupiter dakar 378 eta 454 ahapaldietan; Bk, berriz, Barlaman ezarri du lehenengoan (414) eta ez du bata ere aipatzen bigarrenean (476). Jupiterren aipamenik ez dago testuetan beste inon ere; Barlaman, berriz, beste lau aldiz dator An (416, 418, 435 eta 436) eta hiru aldiz Bn (441, 442 eta 452); guztietan ere Julek aipatzen du laguntza eskatzeko. Beraz, badirudi, jatorrizkoan Jupiterri hel egiten diola Clovis paganoak eta Barlamani, berriz, Julek, eta Bko kopiatzailea izan dela 414. ahapaldian oharkabean nahiz ohartuki Barlaman aldaketa egin duena.

\section{CLOVIS}

A 378 Othoy, favory guitçaq

oro, Jupiter handia,

allemanetan gagnen

eman eçagucq victoria!

\section{FLORINDE}

A 454 Bataila balençan celariq

errege duçu gomendatu,

bay eta bere gincoua

Jupiter invocatu.

\author{
CLOVIS \\ B 414 Othoy, favory guitçaq, \\ oh, Barlaman handia, \\ alemaignetan gaignen \\ eman içaguq victoria!
}

\author{
FLORINDE \\ B 476 Batailla balençan celariq \\ erregue duçu gomendatu, \\ eta bere ginco falxier \\ bihotcez adressatu.
}

Beheko bi ahapaldietan puntuazioa ezberdin eman dugu A eta B eskuizkribuen transkripzioetan. Bren kasuan 106 eta 107. ahapaldien artean puntua ezarri dugu; An, berriz, koma ezarri dugu. Batean zein bestean nahy bada incapable niçan esaldi kontzesiboak bigarren zatia behar du, baina 
ezberdin dator bietan, tartean egindako aldaketaren ondorioz: Bn hurrengo lerroko halere dit acceptatcen da perpausa osatzen duena, bestean, berriz, aurreko ahapaldiak izan behar du esaldia osatzen duena, alegia Clotildak proposizionea azeptatzen du, nahiz eta inkapable den.

\author{
A 67 Hitz haren pian dit, jauna, \\ propositionia acceptatcen, \\ conditioniren pian niq ere \\ noure buria ofritcen,
}

68 nahy bada incapable niçan halaco printce baten, ceren bera den nitçaz satifeit edireiten.
B 106 Hitz haren pian deiçut, jauna, proposicionia acceptaturen, condicioniaren pian niq ere noure buria offritcen.

107 Nahy bada incapable niçan halere dit acceptatcen, ceren bera den nitaz satifet edireiten.

\section{Azken hitzak}

Goiko lerroetan Clovis pastoralaren bi eskuizkributako testuak erkatzen eta aldaerak erakusten saiatu gara. Garrantzitsuenak eta adierazgarrienak eman ditugu, ustez behintzat. Dena den, hasieran esan dugun bezala, Clovis pastoralak, guk aukeratu dugun azterbidetik haratago, beste modu bateko erkaketa eta azterketetarako bide ere ematen du, oso aberatsa baita eskuizkributan.

Guk aipatutako aldaera horiek guztiak argiago ikusi ahal izateko eta hizkuntzazko nahiz literaturako azterketa sakonagoak egin ahal izateko, baina, ezinbesteko iruditzen zaigu eskuizkribu hauen edizio kritiko egokiak egitea. Pastoraletan asko dira oraindik argirik ikusi ez duten eskuizkribuak. Guztira 55 izenburutik gora dira Hérellek (1928) Zuberoako pastoralen katalogoan aipatzen dituenak eta 120tik gora gaur egun liburutegi publikoetan nahiz bilduma pribatuetan gordetzen diren eskuizkribuak. Modu batera edo bestera argitaratu diren pastoral zaharren eskuizkribuetan 16 bat izenburu ezberdin dira, ${ }^{21}$ asko da, beraz, oraindik egiteko dagoena eta are gehiago ondoren testuak aztertu ahal izateko edizio egokiak nahi baditugu.

\section{Aipatutako bibliografia}

Féraud, J.-Fr., 1787-1787, Dictionnaire critique de la langue française, Marseille.

\section{<http://www.lib.uchicago.edu/efts/ARTFL/projects/dicos/>}

Hérelle, G., 1928, Répertoire du théâtre tragique. Catalogue analytique, Imprimerie du Courrier, Baiona.

Léon, A., 1909, Une pastorale basque. Hélène de Constantinople. Étude historique et critique, Librairie Ancienne Honoré Champion, Paris.

Loidi Garitano, A., 1996, "Sainta Catherina pastoralaren XIX. mendeko bi eskuizkribu", ASJU

XXX-2, 497-603.

—. 2004, "Antiokiako San Julianen Pastorala (1770)", ASJU XXXVIII-1 (2004), 1-133.

—. 2008a, "La pastoral suletina: trabajos de investigación y ediciones" (Gasteizen 2008ko

irailaren 10ean "Monumenta Linguae Vasconum proiektua (2002-2008) sei urte ikerketan"

21. Trajeria zaharren eskuizkribuen orain arteko argitalpenen berri laburra eman genuen Loidi 2008a lanean. 
izeneko mintegian irakurritako txostenaren gaztelaniazko bertsioa).

<http://www.ehu.es/monumenta/pdf/mintegia2008/Loidi-La_pastoral_suletina.pdf> —. 2008b, "Clovis pastoralaren eskuizkribuak", 2008ko urrian Euskaltzaindiak Iruñean antolatutako XVI. Biltzarrean aurkeztutako txosten argitaragabea.

Mozos, I., 2000, Jean de Parisen trageria. Doktore tesi argitaragabearen bertsio eguneratua. UPV/EHUko doktore tesiaren izenburu originala: Jean de Paris pastorala, eskuizkribuen azterketa eta iturrien moldamoduak (1994).

Oyharçabal, B., 1991, La pastorale souletine. Édition critique de Charlemagne, ASJU-ren gehigarriak, XVI, Donostia.

Saroïhandy, J., 1927, La pastorale de Roland, Imprimerie du Courrier, Baiona.

Urkizu, P., 2007, Teatro popular vasco. Manuscritos inéditos del siglo XVIII. Estudio y edición, UNED, Madril.

Vinson, J., 1891, Saint Julien d'Antioche, pastorale en langue basque publiée conformément à un manuscrit appartenant à la bibliothèque de la ville de Bordeaux, Vve Moquet, Bordele. 